\title{
Konstruksi Manajemen Kurikulum di Perguruan Tinggi Agama Islam
}

\author{
Irma Suryani Siregar \\ Sekolah Tinggi Agama Islam Mandailing Natal, Indonesia \\ Jl. Prof. Dr. Andi Hakim Nasution, Komplek Stain Madina, Pidoli Lombang, Panyabungan, \\ Kabupaten Mandailing Natal, Sumatera Utara 22976 \\ Email: irmasuryanisiregar2@gmail.com
}

\begin{abstract}
Curriculum is important instrument in university, because it is important aspect being able produce competent graduates who are based on faith and piety and have good morals. in other words, produce students have balance between intellectual, affective, psychomotor and spiritual intelligence. Therefore PTAI including UIN Malang must be able to manage curriculum properly and correctly in order tobe able produce students have balance between intellectual, affective, psychomotor and spiritual intelligence. This research was conducted with a qualitative approach. Data collection technique is done by using interview, observation and documentation methods. Data is checked for correctness, compatibility and reliability through a process of credibility, transferability, dependability and confirmability. Then data were analyzed by means of data reduction, data presentation and drawing conclusions. Findings this study are that curriculum management UIN Malang is implement integration of science and Islam stages of management, both in planning, implementing and evaluating.
\end{abstract}

\section{Keywords: Construction, Management, Curriculum}

Abstrak: Kurikulum merupakan instrumen penting dalam sebuah perguruan tinggi, karena kurikulum tersebut merupakan salah satu aspek penting untuk bisa melahirkan lulusan yang berkompetensi yang dilandasi iman dan takwa serta berakhlakul karimah. dengan kata lain menghasilkan mahasiswa yang memiliki keseimbangan antara kecerdasan intelektual, afektif, psikomotorik dan spiritual. Oleh karena itu PTAI termasuk UIN Malang harus bisa memenej kurikulumnya dengan baik dan benar supaya mampu menghasilkan mahasiswa yang memiliki keseimbangan antara kecerdasan intelektual, afektif, psikomotorik dan spiritual. Penelitian ini dilakukan dengan pendekatan kualitatif. Teknik pengumpulan data dilakukan dengan metode interview, observasi dan dokumentasi. Data diperiksa apakah sudah benar, cocok dan handal melalui proses kredibilitas, transferabilitas, dependebilitas dan konfirmabilitas. Kemudian data dianalisis dengan cara reduksi data, penyajian data dan penarikan kesimpulan. Adapun temuan penelitian ini adalah bahwa manajemen kurikulum di UIN Malang adalah dengan menerapkan integrasi ilmu dan Islam dalam tahapan-tahapan manajemennnya, baik dalam perencanaan, pengimplementasian dan evaluasinya.

Kata Kunci: Konstruksi, Manajemen, Kurikulum

Jurnal Pendidikan Agama Islam Al-Thariqah Vol. 5, No. 2, Juli - Desember 2020

Received: 24 September 2020; Accepted 12 December 2020; Published 14 December 2020

*Corresponding Author: irmasuryanisiregar2@gmail.com 


\section{PENDAHULUAN}

Pendidikan pada hakikatnya aspek yang sangat penting yang mampu membangun dan membentuk watak bangsa yang kuat dan cerdas (Zamroni, 2001: 94). Sehingga pada akhirnya bangsa atau masyarakat yang kuat dan cerdas akan menjadi bangsa yang "mandiri" dalam segala hal (Mulyasa, 2005: 4). Dengan demikian pendidikan diharapkan bisa mencerdaskan bangsa untuk terciptanya kehidupan masyarakat yang mandiri, maju, dan sejahtera. Hal itu tercapai bilamana dalam proses pendidikan bisa mengembangkan semua potensi peserta didik bisa dengan maksimal sesuai dengan tujuan dan falsafah hidup bangsa. Hal ini seiring dengan tujuan pendidikan nasional untuk mengembangkan potensi peserta didik menjadi manusia yang beriman dan bertakwa, berakhlak mulia, sehat jasmani rohani. Dengan kata lain memiliki kecerdasan yang seimbang, yaitu cerdas intelektualnya, fisiknya, afektifnya, psikomotoriknya dan spritualnya (Undang-Undang Republik Indonesia No.20 Tahun 2003: 5-6).

Tujuan pendidikan sebagaimana sudah dijelaskan di atas harus terimplementasi dalam proses pendidikan bagi setiap satuan pendidikan, mulai dari pendidikan terendah sampai pendidikan tertinggi (perguruan tinggi), terlebih lebih Perguruan Tinggi Agama Islam (PTAI) yang berfungsi untuk menghasilkan lulusan yang ahli dalam bidang agama serta mampu mengembangkan iptek yang islami dan bermanfaat bagi kehidupan masyarakat dan bangsa.

Akan tetapi melihat realita yang terjadi dapat dilihat bahwa tujuan PTAI tersebut belum tercapai dengan maksimal. Karena masih banyak lagi ditemukan alumni PTAI yang tidak menggambarkan sosok yang paham ajaran Islam, baik dari segi pemikiran, sikap dan tingkah lakunya di tengah- tengah masyarakat, bahkan kehadiran mereka terkadang dianggap beban moral. Kenapa demikian, karena pengetahuan dan keterampilan mereka tidak bisa diandalkan. Bahkan sikap dan tingkah lakunya tidak menggambarkan sosok sarjana yang agamis dan religius. Padahal sosok mereka diharapkan menjadi garda terdepan untuk menyelesaikan permasalahan umat bukan menambah permasalahan bagi umat.

$\begin{array}{rrcr}\text { Oleh } & \text { karena itu, PTAI } & \text { perlu } \\ \text { mengkaji } & \text { ulang } & \text { dimana } & \text { letak }\end{array}$ permasalahan pengelolaan PTAI tersebut. Salah satu unsur yang sangat urgen adalah kurikulumnya, bagaimana seharusnya manajemen kurikulum di PTAI, apakah sudah tepat atau tidak. Supaya lulusan PTAI mampu menghasilkan mahasiswa yang memiliki keseimbangan antara kecerdasan intelektual, afektif, psikomotorik dan spiritual. Oleh karena itu, perlu untuk manajemen kurikulum yang mampu mengintegrasikan ilmu dan agama Salah satu PTAI yang sudah menerapkan integrasi ilmu dan Islam salah satunya adalah UIN Malang. Oleh karena itu dalam tulisan ini akan diulas dan dijelaskan bagaimana bagaimana manajemen kurikulum di UIN Malang.

\section{KONSEP TEORI}

\section{Konsep Dasar Manajemen Kurikulum}

Manajemen secara sederhana merupakan teknik untuk mencapai tujuan dengan melibatkan orang lain. Sedangkan manajemen dalam arti luas adalah proses merencanakan, mengorganisasikan, mengarahkan, dan mengendalikan sumber daya yang ada untuk mencapai tujuan yang sudah ditetapkan dengan cara yang efektif dan efisien (Usman, 2010: 5).

Dalam praktiknya, jauh sebelum lahir teori modern tentang manajemen, Rasulullah SAW sudah mempraktikkan manajemen tersebut. Karena hakikat dari manajemen itu adalah mengerjakan 
segala sesuatu dengan rapi, benar, tertib, dan teratur, atau disebut dengan konsep itqan. Hal tersebutlah yang Rasulullah SAW terapkan dalam mengerjakan segala sesuatu.

Dalam sebuah hadits yang diriwayatkan oleh Muslim dijelaskan bahwa sesungguhnya Allah menyukai hambanya yang apabila mengerjakan sesuatu pekerjaan, dikerjakan dengan cara itqan (tepat, terarah, jelas dan tuntas (Al-Thabrani, 2005: 408).

Dalam terminologi Islam, itqan adalah melakukan suatu tugas dengan kualitas terbaik (Antonio 2011: viii-ix).

Istilah lain dari itqon adalah Ihsan Sebagaimana dijelaskan dalam sebuah hadits bahwa Allah SWT mewajibkan hambanya berlaku ihsan dalam segala sesuatu (Yahya Ibn Syarifuddin, Hadits Arba'in Annawawi Nomor 17). Kata ihsan dapat diartikan melakukan segala sesuatu dengan upaya yang maksimal dan optimal untuk mendapatkan hasil yang berkualitas dan sempurna. Sehingga dalam beribadah pun, apabila kita beribadah dengan ihsan maka pelaksanaannya bukan sekedar memenuhi syarat dan rukun saja, melainkan dilakukan dengan yang cara terbaik, dan semata-mata mengharapkan ridho Allah SWT.

Itqon dan Ihsan harus tergambar dalam setiap aktifitas seorang muslim, yakni berusaha melakukan yang terbaik dalam setiap aktivitas (Fathani, tt: 723). Sehingga apapun aktifitas seorang muslim, baik itu aktifitas beribadah, bersosial, berekonomi bahkan berpolitik, semuanya bernilai ibadah

Dengan demikian dapat dipahami bahwa ajaran Islam menganjurkan kepada umatnya untuk melalukan segala sesuatu dengan maksimal, optimal dan totalitas, dengan istilah lain mampu bermanajemen. Karena segala sesuatu kalau dimenej dengan baik, maka hasilnya akan maksimal dan sempurna dan mendapatkan keberkahan dari Allah SWT.

Begitu juga halnya dengan pendidikan. Dalam sistem pendidikan, ada satu aspek yang sangat urgen untuk dimenej, yaitu kurikulum. Karena kurikulum tersebut merupakan jantung dalam sebuah satuan pendidikan. Maka kurikulum itu harus di menej dengan baik.

Tapi sebelumnya harus di pahami, apa sih kurikulum itu? Kurikulum merupakan pedoman penyelenggaraan pembebelajaran yang terdiri dari perencanaan dan pengaturan mengenai tujuan, isi dan bahan pelajaran serta metode yang digunakan proses pembelajaran (Undang-Undang Sisdiknas, 2003: ayat 19). Selanjutnya dijelaskan bahwa kurikulum pendidikan tinggi merupakan seperangkat rencana dan pengaturan mengenai isi maupun bahan kajian dan pelajaran serta cara penyampaian dan penilaian yang digunakan sebagai pedoman penyelenggaraan kegiatan belajarmengajar di perguruan tinggi.

Dari uraian di atas dapat dipahami bahwa kurikulum merupakan aspek penting dalam pendidikan. Oleh karena itu perlu dimenej seoptimal mungkin supaya perencanaan, pelaksanaan dan evaluasi kurikulum tersebut berjalan dengan efektif dan efisien. Inilah hakikat dari manajemen kurikulum tersebut.

Adapun manfaat manajemen kurikulum adalah: (a) memanfaatkan daya kurikulum dengan efisien, (b) memperlakukan peserta didik secara baik, (c) menyesuaikan pembelajaran dengan kebutuhan peserta didik dan lingkungannya (d) mengefektifkan kinerja pendidik dan peserta didik untuk mencapai tujuan pembelajaran, (e) mengefektifkan proses pembelajaran (f) memberikan peluang bagi masyarakat untuk berperan dalam pengembangan kurikulum (Rusman, 2009: 5). 
Dari uraian di atas dapat dipahami bahwa manajemen kurikulum itu merupakan komponen yang sangat urgen di dunia pendidikan. Karena dengan manajemen kurikulum, maka pembelajaran akan berjalan dengan maksimal.

\section{Fungsi Manajemen Kurikulum}

Fungsi manajemen kurikulum secara hakikatnya terbagi tiga komponen, yaitu, perencanaan kurikulum, implementasi kurikulum dan evaluasi kurikulum.

\section{Perencanaan Kurikulum}

Dalam merencanakan kurikulum, hal yang perlu dipikirkan adalah bagaimana cara melahirkan lulusan yang memiliki kompetensi. Kompetensi itu pada hakikatnya merupakan perpaduan antara penguasaan ilmu, ketrampilan dan sikap dalam melaksanakan suatu tertentu pekerjaan. Sehingga orang dikatakan berkompetensi apabila ia memiliki ilmu, keterampilan atau keahlian dan sikap yang baik sesuai dengan tuntutan pekerjaan tersebut.

Oleh karena itu, dalam merencanakan sebuah kurikulum, ada beberapa tahapan yang harus dilakukan yakni (1) menetapkan profil lulusan (bagaimana sosok /gambaran lulusan yang diharapkan) (2) merumuskan kompetensi lulusan (kompetensi apa saja yang harus dimiliki lulusan tersebut), (3) mengkaji kandungan dari setiap elemen kompetensi apakah sudah sesuai atau belum, (4) memilih bahan kajian, (5) memperkirakan dan menetapkan beban (sks) (6) membentuk mata kuliah, (7) menyusun struktur kurikulum, mengembangkan silabus dan satuan acara perkuliahan (Kunaefi, 2008: 14).

Kalau tahapan-tahapan tersebut sudah dibuat, maka kurikulum sudah siap untuk diimplementasikan dalam kegiatan pembelajaran.

\section{Implementasi Kurikulum}

Hal pertama yang dibutuhkan untuk mengimplementasikan kurikulum adalah proses pembelajaran, yang mana didalamnya diperlukan berbagai kompetensi yang berkaitan dengan pembelajaran, termasuk kompetensi pendidik. Adapun kompetensi pendidik yang dimaksud antara lain, menguasai materi atau bahan perkuliahan, menguasai strategi, metode dan teknik pembelajaran, dan trampil dalam penggunaan dan pemanfaatan sumber perkuliahan. (Muhaimin, 2008: 29.)

Selain proses pembelajaran, evaluasi hasil belajar juga merupakan elemen penting dalam pengimplementasian kurikulum. Karena Evaluasi hasil belajar merupakan cara untuk mengukur tingkat penguasaan kompetensi yang sudah diperoleh peserta didik. Sehingga evaluasi belajar harus mampu mengukur tingkat kemampuan knowledge (kognitif), skill (psikomotorik) dan attitude (afektif). Untuk melaksanakan evaluasi yang sesuai dengan ketiga kompetensi tersebut, pendidik harus mampu memilih dan menggunakan berbagai instrumen evaluasi. Dalam hal memilih instrumen evaluasi harus disesuaikan dengan wilayah kompetensi yang akan dievaluasi, apakah itu kognitif, afektif atau psikomotorik. ((Muhaimin, 2008: 30).

Evaluasi Kurikulum

Evaluasi kurikulum merupakan pengumpulan informasi terkait kurikulum yang sudah diterapkan sebagai bahan pertimbangan untuk memberikan masukan ke depannya. (Hasan, 2008: 41).

Model evaluasi kurikulum pada umumnya menggunakan model evaluasi CIPP (context, input, process, dan product).

Pertama, context evaluation yaitu evaluasi konteks segala sesuatu yang melatarbelakangi lahirnya dokumen kurikulum. Pada umumnya evaluasi dokumen kurikulum dilakukan untuk melihat apakah kurikulum tersebut sesuai dengan kebutuhan masyarakat dan dunia kerja. Ini disebut dengan istilah need assessment. Need assessment 
berfungsi untuk mengetahui dan menyesuaikan apa yang dibutuhkan masyarakat pada satuan pendidikan tersebut. (Hasan, 2008 : 137) Kebutuhan masyarakat pasti berbeda tergantung keadaan lingkungan sosial, budaya, ekonomi, ilmu teknologi masyarakat tersebut. Sehingga kurikulum yang diberlakukan juga tidak bisa sama karena konteks yang berbeda tersebut. Sehingga berbeda satuan pendidikan, pasti berbeda kurikulumnya.

Kedua, input evaluation (evaluasi terhadap masukan) yaitu input (masukan) terdiri dari komponenkomponen mempengaruhi kurikulum secara langsung, yaitu ketersediaan sumber daya, baik sumber daya manusia (SDM) sumber daya non manusia, dokumen kurikulum, dan kesiapan peserta didik (mahasiswa). Dengan demikian dapat dipahami komponen yang langsung mempengaruhi keberhasilan suatu kurilum itu antara lain dokumen kurikulum, kompetensi pendidik, sarana dan prasarana serta kesiapan peserta didik Oleh karena itu, komponenkomponen tersebut harus lengkap dan berkualitas supaya kurikulum bisa tercapai dengan maksimal (Hasan, 2008: 140).

Ketiga, process evaluation (evaluasi terhadap proses) yaitu evaluasi proses ini dapat dilakukan dengan evaluasi internal, yaitu dengan menunjuk dosen sejawat sebagai evaluator. Karena apabila evaluator dalam evaluasi proses merupakan bagian dari pelaksana langsung yaitu dosen, maka masukan itu akan mudah, karena dia memahami sepenuhnya apa yang terjadi. Jika evaluator itu pimpinan, seperti rektor, wakil rektor, dekan, wakil dekan atau ketua jurusan, maka ada keuntungan yang dimilikinya sebagai pimpinan, yaitu wewenang formal yang dimilikinya. Para dosen akan mendengar dan segera melakukan masukan yang diberikan sehingga pelaksanaan proses implementasi dapat berjalan sesuai dengan apa yang direncanakan dalam dokumen kurikulum (Hasan, 2008: 149). Keempat, output evaluation (evaluasi hasil/produk) yaitu evaluasi hasil dapat dibedakan dengan dua istilah yaitu output dan outcomes. Evaluasi hasil out put didasarkan pada kategori hasil belajar, yaitu kognitif, afektif dan psikomotorik. (Hasan, 2008 : 149) Sedangkan evaluasi outcomes dapat dilihat dari keberadaan alumninya.

\section{METODE PENELITIAN}

Adapun pendekatan yang dilakukan dalam penelitian ini adalah pendekatan kualitatif. Teknik pengumpulan data dilakukan dengan metode interview, observasi dan dokumentasi. Setelah itu data diperiksa apakah sudah benar, cocok dan handal melalui proses kredibilitas, transferabilitas, dependebilitas dan konfirmabilitas. Kemudian data dianalisis dengan beberapa tahapan, yaitu reduksi data, penyajian data dan penarikan kesimpulan.

\section{HASIL DAN PEMBAHASAN}

\section{Perencanaan Kurikulum Universitas di UIN Malang}

Perencanaan kurikulum dilakukan dengan mengembangkan kurikulum tersebut sesuai visi dan misi kampus, kemudian melakukan analisis kebutuhan stakeholder. Stakeholder yang paling utama adalah masyarakat. Saat sekarang ini, masyarakat mengharapkan lulusan PTAI adalah lulusan yang yang Memiliki kemampuan seimbang antara kemampuan intelektual, kemampuan afektif, kemampuan psikomotorik dan kemampuan spiritual. Oleh karena itu UIN Malang mengembangkan kurikulum yang bisa melahirkan mahasiswa yang Memiliki kemampuan seimbang antara kemampuan intelektual, kemampuan afektif, kemampuan psikomotorik dan kemampuan spiritual. Dengan demikian, harus dibekali ilmu dan teknologi sesuai 
dengan bidang atau jurusannya, juga diberikan ilmu dan pengetahuan yang bisa meningkatkan keimanan dan ketakwaan mahasiswa. Hal ini tergambar pada metafora pohon ilmu UIN Malang. Yang mana setiap mahasiswa dari jurusan manapun wajib mempelajari ilmu keislaman (al-Quran, hadist, akhlak dan ilmu keislaman lainnya)

Setelah melakukan analisis stakeholders, kemudian dilanjutkan dengan workshop Kurikulum untuk terus mengupdate kurikulumnya dan meningkatkan kualitas dan kompetensi dosen dalam mengimplementasikan kurikulum tersebut. Setelah itu, masingmasing dosen wajib membuat silabus dan SAP.

Setelah semua silabus dan SAP mata kuliah univertas terkumpul, selanjutnya diadakan pembahasan yang diadakan oleh masing-masing komisi atau team. Selanjutnya akan dilakukan perancangan buku ajar. Buku ajar yang dirancang tersebut harus menggambarkan integrasi ilmu dan Islam.

Berdasarkan tahapan-tahapan yang dilakukan UIN Malang dalam merencanakan kurikulum, menurut analisis penulis sudah sesuai dengan pendapat Muhaimin, dkk, Oemar Hamalik, dan Tresna Dermawan Kunaefi. Bahwa dalam mengembangkan kurikulum harus sesuai dengan visi dan misi lembaga pendidikan, kemudian melakukan analisis kebutuhan stakeholder, menyusun profil lulusan, menetapkan kompetensi lulusan berdasarkan profil lulusan, menentukan bahan kajian sesuai dengan bidang IPTEKS program studi, menetapkan sks, menyusun struktur kurikulum dengan cara mendistribusikan mata kuliah tersebut dalam semester, mengembangkan rancangan perkuliahan berupa silabus dan satuan acara perkuliahan (SAP). Akan tetapi yang dijelaskan oleh Muhaimin, dkk. Oemar Hamalik, Lias Hasibuan, dan Tresna Dermawan Kunaefi dkk itu adalah perencanaan kurikulum dalam lingkup yang lebih luas yaitu kurikulum perguruan tinggi secara keseluruhan baik itu mata kuliah universitas maupun mata kuliah khusus program studi. Sementara dalam tulisan ini hanya fokus pada matakuliah universitas atau matakuliah institusi saja.

\section{Implementasi Kurikulum Universitas di UIN Malang}

Pengimplementasian kurikulum universitas dilakukan dengan cara setiap dosen mengimplementasikan rancangan perkuliahannya (silabus dan SAP) nya dalam proses pembelajaran dengan metode yang bervariasi. Akan tetapi dalam pengimplementasian kurikulum tersebut harus menerapkan integrasi ilmu dan agama sebagai ciri khas UIN Malang. Setiap dosen wajib menerapkan integrasi antara ilmu dan Islam dalam perkuliahan pada semua mata kuliah.

Ada beberapa opsi yang dilakukan dosen dalam mengintegrasikan ilmu dan Islam dalam perkuliahan, yaitu Pertama, semua dosen "non agama" harus mengintegrasikan ilmu yang diajarnya dengan Islam. Misalnya dalam mata kuliah ilmu sosial dasar, dosen harus bisa meningkatkan kepekaan mahasiswa terhadap masalah-masalah sosial dan budaya yang terjadi di sekitarnya kemudian memecahkan permasalahan melalui pendekatan utuh, menyeluruh dan komprehenshif dengan menggunakan pendekatan al-Qur'an dan hadits serta sumber-sumber sosial lainnya. Jadi dosen harus bisa mengaitkan materi yang diajarnya itu dengan nilai-nilai Islam. Begitu juga halnya dengan matakuliah "non agama" lainnya, seperti ilmu alamiah dasar, filsafat ilmu, dan matakuliah lainnya. Jadi, dosen yang berlatar belakang pendidikan "umum", dituntut mampu mengintegrasikan ilmu dan Islam.

Oleh karena itu setiap tahun ada pelatihan atau workshop kurikulum universitas, dosen yang berlatar belakang 
umum diberikan wawasan keagamaan atau integrasi. Sebaliknya dosen yang mengajarkan studi keislaman, diharapkan pula bisa mengintegrasikan mata kulaih yang diampunya dengan latar belakang (jurusan) mahasiswa yang diajarnya. Berbagai matakuliah keislaman, seperti studi al-Qur'an, studi Hadits, dan lain sebagainya difokuskan (fokus on cencern) untuk bisa menggali nilai-nilai Islam kemudian mengintegrasikannya dengan ilmu (jurusan masing-masing mahasiswa). Dengan demikian, di fakultas ekonomi misalnya, muatan kurikulum untuk studi al-Qur'an tentang ekonomi dan Hadits-hadits Nabi tentang ekonomi. Demikian pula untuk studi tasawuf, studi fikih, dan studi keislaman yang lain selalu diupayakan untuk bisa dikaitkan dengan masalah ekonomi. Itu semua dilakukan dengan harapan untuk memperkuat wawasan akademik mahasiswa agar mereka mampu menganalisis keilmuannya sesuai jurusan masingmasing dari perspektif Islam. Sebagai konsekuensinya, setiap tugas manusia, misalnya makalah, laporan penelitian (skiripsi) dalam analisisnya harus diintegrasikan dengan nilai-nilai keislaman yang sudah pernah mereka terima dari mata kuliah studi al-Qur'an atau studi hadits.

Berdasarkan penerapan integrasi ilmu dan Islam yang sudah dilakukan oleh dosen UIN Malang, menurut analisis penulis, ada tiga bentuk atau model integrasi di UIN Malang, yaitu:

Pertama, mengaitkan materi perkuliahan dengan kajian keislaman (baik ayat al-Qur'an, hadits, maupun pendapat ulama atau ilmuan muslim yaitu pada matakuliah "non agama", seperti ilmu alamiah dasar, ilmu sosial budaya dasar, filsafat dan pancasila. Secara umum silabusnya sama untuk semua jurusan, akan tetapi pengembangannya sesuai dengan jurusan masing-masing. Selain dosen mengembangkannya sesuai dengan jurusan, dosen juga mengintegrasikannya dengan Islam. Dosen mencari ayat atau hadits atau bahkan pendapat ulama dan ilmuan muslim yang sesuai dengan materi yang dibahas. Kalau dosennya merasa kesulitan, maka yang bersangkutan akan bertanya dan berdiskusi dengan dosen lain yang dianggap lebih ahli. Begitu juga bagi mahasiswa, dalam membuat makalah atau tugas harus mengkaitkannya dengan ayat al-Qur'an atau hadits maupun pendapat ulama dan ilmuan muslim.

Cara integrasi model pertama sebagaimana dijelaskan di atas yaitu mengkaitkan materi perkuliahan dengan ayat al-Qur'an, atau hadist maupun pendapat ulama sesuai konsep islamisasi ilmu yang sudah ditawarkan oleh para ilmuan islam. Islamisasi ilmu berarti mengislamkan ilmu pengetahuan yang diperoleh dari luar Islam dan bahkan sudah menjadi kiblat dalam pengembangan pendidikan di dunia saat ini. Sehingga perlu dilakukan proses islamisasi ilmu supaya ilmu pengetahuan yang berasal dari produk luar Islam (Barat) lebih berciri khas "Islami".

Para ilmuan muslim menawarkan beberapa model Islamisasi ilmu, yaitu: (a) model paragmatis, model ini lebih kepada labelisasi (memberikan label saja) dan terkesan bersifat justifikasi; (b) model idealisasi, yaitu al-Qur'an dan hadist dijadikan sebagai hudan (petunjuk) untuk menilai dan menetapkan kebenaran teori ilmu pengetahuan yang ada; (c) model critical concept/theory, yaitu adanya saling memberikan masukan dan kritikan bagi kedua belah pihak, yaitu antara temuan barat dengan hasil pemikiran ulama, karena menurut model ini teori barat dan pemikiran ulama sama-sama bersifat relative kebenarannya, sehingga perlu dialog antara keduanya untuk saling memberi masukan; (d) model rekonstruksi, yaitu islamisasi ilmu dilakukan dengan cara menyusun ulang epistemologi ilmu pengetahuan yang sudah ada kemudian dikonstruksikan 
sesuai dengan pandangan Islam (Muhaimin, 2003: 67).

Kedua, mengaitkan kajian keislaman dengan keilmuan (jurusan) mahasiswa. Maksud bentuk ini adalah mengaitkan kajian keislaman dengan keilmuan (jurusan) mahasiswa dilakukan pada matakuliah-matakuliah keislaman, seperti ululumul Qur'an, ulumul hadits, fikih, ilmu kalam, tasawuf dan sejarah peradaban Islam. Secara umum silabusnya sama untuk semua jurusan, akan tetapi pengembangannya sesuai dengan jurusan masing-masing. Dosen pada matakuliah keislaman, selain menguasai bidang ilmu yang diajarnya, mereka juga mengintegrasikan materinya dengan latar belakang keilmuan (jurusan) mahasiswa. Pada matakuliah studi al-Qur'an dan hadits, maka ayat dan hadits yang dibahas adalah sesuai dengan jurusan masingmasing. Misalnya pada jurusan biologi, maka ayat yang dibahas ayat-ayat tentang biologi. Begitu juga pada matakuliah studi hadits, maka hadits yang dibahas adalah hadits yang berkaitan dengan biologi. Demikian pulalah pada jurusan-jurusan yang lain, seperti psikologi, tarbiyah, saintek dan lain sebagainya.

Penemuan-penemuan ilmiah yang sangat menakjubkan yang sudah disosialisasikan oleh para ilmuan dari berbagai bidang kajian, seperti kandungan yang terdapat dalam kotoran babi, yang oleh Islam cara membersihkan harus dengan cara samak, yaitu membersihkannya dengan air yang bercampur tanah. Ternyata hikmah syariat Islam tersebut ditemukan melalui hasil penelitian para ilmuan. Begitu juga penemuan penemuan lain, yang terkait fenomena alam dan fenomena sosial seperti tentang gerhana matahari, gerhana bulan, keajaiban tulang ekor, akibar dari seks bebas dan lain sebagainya. Sehingga dengan penemuan penemuan ilmiah tersebut hikmah dari ajaran atau syariat Islam lebih tersingkap dan diharapkan lebih meningkatkan keimanan seorang muslim dalam menjalankan syariat agamanya.

Penemuan-penemuan

ilmiah modern sangat membantu umat Islam untuk memahami ajaran dan hikmah dari syariat tersebut. Sehingga oleh para oleh beberapa sarjana muslim menjadikan penemuan-penemuan ilmiah tersebut sebagai media atau sarana dakwah untuk mendakwahkan meyakinkan orang bahwa Islam merupakan agama yang benar, karena benar berasal dari sang Maha Benar, yaitu Allah SWT.

Akan tetapi kita juga harus hati-hati, banyak kalangan kemudian melakukan justifikasi ilmiah dengan mengutip ayatayat al-Qur'an atau Hadits yang relevan dengan penemuan-penemuan ilmiah tersebut. Atau disebut dengan ayatisasi sains (Kartanegara, 2011: Xv-xvii). Oleh karena itu, hendaknya kita harus bersikap benar dan kritis tentang hal ini, yakni sains tentang kebenaran agama dan kebenaran ilmiah. Kita harus bisa menilai mana keterangan ilmiah yang cocok dan tidak bertentangan dengan agama Islam, dan mana yang bertentangan, sehingga kita perlu menolaknya. Juga ketika kita melakukannya, sekali-kali bukan karena sifat inferior kita terhadap sains, karena kebenaran agama jauh lebih unggul dan mutlak ketimbang kebenaran sains, tetapi semata-mata karena keyakinan kita bahwa kedua ayat Allah tersebut (ayat qawliyah dan kawniyah) benar-benar berasal dari Tuhan kita, yaitu Allah SWT sebagai sumber sejati bagi keduanya.

Dari penjelasan di atas dapat di pahami bahwa sebenarnya Islam, ilmu dan sains sudah memiliki integrasi pada dasarnya, artinya tanpa diintegrasi pun islam dan sains itu sendiri sudah terintegrasi, karena bersumber dari yang satu yaitu Allah. Ketika membahas sains yang berasal dari fenomena alam atau fenomena sosial itu berasal dari ayat kauniyah Allah, sementara ketika membahas al-Qur'an dan Hadits, itu bersumber dari ayat qauliyah Allah. 
Sehingga apabila terdapat pemisahan atau dikotomi antara Islam sains dan ilmu, itu hanya karena kesalahpahaman saja. Maka disinilah perlunya reintegrasi ilmu dan Islam, supaya tidak ada kesalahpahaman lagi (Hidayat, 2015: 309).

Ketiga, integrasinya pada objek kajian. Dalam mengintegrasikan matakuliah-matakuliah kebahasaan, yaitu Bahasa Arab, Bahasa Inggris dan Bahasa Indonesia, maka materi-materinya tentang keislaman, akhlak mulia, dan hal apa saja yang mengandung nilai-nilai Islam. Jadi pembahasannya tetap empat hal itu yaitu ketrampilan membaca, menulis, berbicara dan menyimak. Tapi contoh-contoh atau materi yang dibahas dalam perkuliahan mengandung nilainilai Islam. Pada dasarnya matakuliah kebahasaan itu bertujuan memberikan wawasan dasar ihwal wacana dan pengetahuan kebahasaan agar mahasiswa mampu memahami penggunaan bahasa sesuai kaidah dan ketentuan baik dalam berkomunikasi verbal dan non verbal. Terutama diarahkan supaya mahasiswa memiliki kemampuan menulis karya ilmiah dan artikel populer dengan mempraktikkan pengetahuan kebahasaan dan tata bahasa yang sudah dimilikinya.

Dengan matakuliah kebahasan ini, terutama Bahasa Arab dan Bahasa Inggris ini diharapkan bisa membantu mahasiswa untuk bisa mengkaji literaturliteratur yang berbahasa Arab dan Bahasa Inggris. Makanya materi-materi yang diajarkan itu disesuaikan dengan keilmuan (jurusan) mahasiswa. Misalnya Bahasa Arab di ekonomi, maka materi yang dibahas sesuai dengan tema-tema ekonomi. Begitu juga dengan jurusanjurusan lain, seperti psikologi, biologi, fisika, pendidikan agama Islam dan seterusnya. Dengan demikian matakuliah bahasa Arab dan bahasa Inggris ini diharapkan bisa menjadi modal bagi mahasiswa untuk mengkaji referensi yang berbahasa asing, sehingga membantu proses akademik mereka.

Hal ini sebagaimana dijelaskan Muhaimin bahwa integrasi ilmu dan Islam bisa dilakukan dengan berupaya mengimplementasikan nilai-nilai ajaran Islam pada materi pelajaran dan pada proses pembelajaran (Muhaimin, 2011: 80). Seperti memberikan motivasi kepada mahasiswa bahwa dengan menulis artikel islami, kita bisa berdakwah, bisa memberikan gagasan-gagasan/ide-ide cemerlang bagi orang lain. Hal itu merupakan ibadah ataupun 'amal jariyah.

Dari beberapa model integrasi di atas, dapat dipahami bahwa inti dari integrasi ilmu itu adalah menjadikan Islam sebagai landasan pengembangan ilmu pengetahuan, dengan kata lain ilmu pengetahuan itu harus benar-benar mengandung nilai-nilai islami (Firdaus, 2019: 31).

\section{Evaluasi Kurikulum Universitas di UIN Malang}

Dalam mengevaluasi kurikulum, UIN Malang menggunakan model CIPP (context, input, process, product).

Evaluasi Konteks

Evaluasi konteks ini dilakukan untuk mengevaluasi kurikulum apakah sesuai dengan perkembangan zaman atau kebutuhan masyarakat. Evaluasi konteks ini dilakukan untuk memenuhi harapan stakeholder terhadap perguruan tinggi, sehingga lulusannya mampu mewujudkan harapan stakeholder. Dalam hal ini UIN Maulana Malik Ibrahim juga mengevaluasi kurikulumnya, seperti tahun 2015, kurikulum universitas yang dikembangkan berbasis KKNI dan integrasi menuju world class university. Oleh karena itu, kurikulum universitas memiliki tiga hal tersebut, yaitu: KKNI sebagai kurikulum nasional dalam rangka kualifikasi nasional Indonesia, kemudian integrasi sebagai ciri khas UIN dan dikaitkan dengan world class university.

Evaluasi Input (Masukan) 
Evaluasi Input (masukan) yaitu mengevaluasi segala sesuatu yang berhubungan langsung dengan pengimplementasian kurikulum. Seperti kelengkapan dokumen kurikulum, kompetensi dosen, kesiapan mahasiswa, kelengkapan media, sarana dan prasarana. Untuk lebih jelasnya dapat dilihat sebagai berikut:

Pertama, Evaluasi Dokumen Kurikulum. Evaluasi dokumen ini dilakukan dengan meninjau kembali dokumen kurikulum yang sudah dirumuskan pada tahun sebelumnya sebagai upaya untuk selalu mengupdate kurikulum tersebut.

Kedua, ketersediaan Dosen. Dalam perekruran dosen, UIN Malang menetapkan kriteria khusus, yaitu mencari dosen yang latar belakang pendidikannya alumni pesantren atau yang pernah mondok kemudian lebih lebih mengutamakan lulusan perguruan tinggi terkemuka dan sudah diakui kompetensi lulusannya.

Selain itu, harus memenuhi kriteria dosen sebagaimana tergambar dalam profil ideal dosen sebagai berikut (1) menjadi pribadi muslim sejati; (2) berwawasan luas dan profesional (3) memiliki jiwa kreatif, dinamis, dan inovatif dalam pengembangan ilmu pengetahuan; (4) menjadi uswah dan qudwah dimana pun berada.; (5) disiplin dan patuh terhadap aturan yang berlaku; (6) mempunyai nalar yang logis; (7) kinerjanya bagus dan produktif; (8) bijaksana dalam menyikap dan menyelesaikan dalam berbagai masalah yang dihadapinya; (9) antisipatif dan proaltif dalam menghadapi masa depan.

Profil ideal dosen sebagaimana dijelaskan di atas harus dimiliki oleh semua dosen, supaya visi dan misi yang sudah ditetapkan dapat terwujud. Sehingga menjadi keharusan bagi kampus untuk memfasilitasi kegiatan kegiatan dalam rangka peningkatan kualitas dosen supaya tercapai sosok dosen sebagaimana tergambar dalam profil ideal dosen tersebut.

Ketiga, kelengkapan Sarana dan Prasarana. Hal ini juga merupakan komponen penting untuk mendukung keberhasilan suatu kurikulum. Karena tanpa sarana dan prasarana yang lengkap, implementasi kurikulum tidak akan terlaksana dengan maksimal.

Kampus sudah menyediakan sarana dan prasarana yang lengkap dan berkualitas, seperti ruang perkuliahan yang lengkap dan memadai, laboratorium, gedung olar raga, masjid, ma'had (asrama, pesantren mahasiswa) perpustakaan dan lain sebagainya.

Selain sarana dan prasarana di atas, kampus juga menyediakan sarana dan prasarana penunjang dalam rangka pengimplementasian integrasi ilmu dan Islam, yaitu lembaga kajian al-Qur'an dan sains, hai'ah tahfidh al-Qur'an, pusat kajian sains dan Islam dan kajian tarbiyah ūlu al albāb.

Dengan kelengkapan sarana dan prasarana tersebut di atas, diharapkan mampu untuk dapat mewujudkan pengimplementasian terkait dengan kurikulum khususnya penerapan integrasi ilmu dan Islam.

Keempat, kesiapan Mahasiswa. Pada umumnya mahasiswa merespon positif dan mengafresiasi pelaksanaan integrasi ilmu dan Islam. Karena selain mereka menguasai teori-teori konvensional, mereka juga mengetahui persfektif Islamnya.

Evaluasi Proses

Evaluasi proses dilakukan untuk mengevaluasi proses implementasi kurikulum dalam perkuliahan. Ada tiga hal yang dilakukan, yaitu melihat jurnal masing-masing dosen selama perkuliahan, mewawancarai mahasiswa, dan melakukan pengukuran kepuasan mahasiswa terhadap kinerja dosen. Aspek kinerja mengajar dosen tersebut mencakup 5 aspek yaitu: (1) ketrampilan mengajar; (2) pengembangan kreativitas; 
(3) pengetahuan substansif; (4) sikap akademik; (5) kedisiplinan.

Dalam rangka evaluasi proses ini, setiap tahun kampus melakukan survey untuk mengetahui tingkat kepuasan mahasiswa terhadap kinerja dosen. Hasil survey ini dijadikan bahan untuk mengevaluasi kinerja dosen dan sebagai upaya untuk memperbaiki mutu secara terus menerus.

Evaluasi proses ini sebenarnya lebih efektif dilakukan dengan evaluasi internal, yaitu dengan menunjuk dosen sejawat sebagai evaluator ataupun pimpinan sendiri yang menjadi evaluator. Dengan demikian, otomatis para dosen akan segera memperbaiki kinerja nya dalam mengajar sesuai dengan masukan dari pimpinan tersebut. (Hasan, 2008: 149).

\section{Evaluasi Hasil}

Evaluasi hasil biasanya dilakukan untuk mengetahui tingkat keberhasilan mahasiswa dalam perkuliahan. Secara umum, evaluasi terhadap hasil belajar mahasiswa dibuat dalam bentuk Quis, tugas, UTS dan UAS. Akan tetapi permasalahannya, instrumen penilaian yang sering digunakan dosen sebagian besar masih bersifat penilaian kognitif. Hal ini dapat dilihat dari soal yang diujikan. Sementara menurut para ahli, evaluasi hasil didasarkan pada kategori hasil belajar yang bersifat kognitif (intelektual), afektif (sikap) dan psikomotorik (skill). (Hasan, 2008: 149).

Oleh karena itu, dalam mengevaluasi hasil belajar peserta didik, penilaian yang dibuat harus mewakili semua kemampuan peserta didik, baik kemampuan dalam kognitif, afektif dan psikomotorik. Dan bahkan dalam dunia pendidikan sekarang dikenal dengan istilah kecerdasan intelektual, kecerdasan emosional dan kecerdasan spritual.

Terkait kemampuan mahasiswa dalam mengintegrasikan ilmu dan Islam masih bervariasi. Secara umum mahasiswa mampu membuat makalah dengan mengintegrasikannya dengan kajian keislaman, baik berupa ayat alQur'an, Hadits maupun pendapat para ulama atau ilmuan muslim, karena dalam silabus dosen sudah mencantumkan daftar rujukan masing-masing materi yang akan dibahas selama perkuliahan. Akan tetapi dalam membuat tugas lain seperti menulis laporan hasil survey di lapangan, masih ada beberapa mahasiswa yang belum mampu menganalisis permasalahan tersebut dengan pendekatan al-Qur'an atau hadits. Begitu juga halnya pada waktu ujian tertulis, kalau soalnya minta pendapat atau memberikan solusi terhadap suatu permasalahan, mahasiswa belum semuanya mampu mengintegrasikan ilmu dan Islam. Akan tetapi mahasiswa yang berlatar belakang dari pesantren, pada umumnya mampu mengaitkannya dengan al-Qur'an dan Hadits. Sedangkan alumni SMA/SMK, mereka masih kesulitan menganalisis suatu permasalahan dengan pendekatan al-Qur'an dan Hadits, biasanya mereka hanya mengandalkan logika saja.

Secara umum, para mahasiswa mampu menguasai standar kompetensi tiap-tiap matakuliah universitas yang sudah ditetapkan dan lulus tepat waktu.

Sedangkan outcome dari UIN Malang ini dapat dilihat dari pengakuan masyarakat. Hal ini dapat dilihat dari tahun ke tahun peminat yang masuk terus meningkat.

Selain melihat animo masyarakat memasukkan anaknya ke UIN Malang, pengukuran outcome nya juga bisa dilihat dari keberadaan alumninya.

Hal ini bisa dilihat dari eksistensi alumni di berbagai sektor, ada yang menjadi akademisi, guru, dosen, bahkan ada yang menjadi birokrat (menjadi bupati, walikota bahkan menteri), ada juga yang politisi (pengurus partai dan menjadi anggota DPR dan DPD) , ada yang menjadi tokoh muhammadiyah dan 
Nahdatul Ulama. Bahkan ada ayang menjadi pebisnis dan militer.

Eksistensi alumni yang menyebar ke berbagai sector ini merupakan salah satu indikasi keberhasilan perguruan tinggi agama Islam yang membekali mahasiswa dan lulusannya keterampilan hardskill dan softskill sehingga bisa berkontribusi dalam kehidupan berbangsa dan bernegara di berbagai sector sesuai dengan bidangnya masing-masing.

\section{PENUTUP}

Pada hakikatnya Perguruan Tinggi Agama Islam lahir sebagai upaya untuk melahirkan sosok yang ahli agama yang memiliki kemampuan dalam pegembangaan iptek dan budaya Islam guna untuk meningkatkan kesejahteraan masyarakat. Dengan demikian, lulusan PTAI adalah lulusan yang memiliki kecerdasan seimbang, yaitu kecerdasan intelektual, afektif, psikomotorik dan sprirualnya.

Untuk melahirkan lulusan yang demikian, salah satu aspek yang perlu diperhatikan adalah kurikulumnya. Kurikulum tersebut harus dimenej, dengan kata lain manajemen kurikulumnya harus bagus. Dan harus menerapkan integrasi ilmu dan Islam.

UIN Malang termasuk kampus yang menerapkan integrasi ilmu dan Islam. manajemen kurikulumnya dengan menerapkan integrasi ilmu dan Islam dalam tahapan-tahapan manajemennnya, baik dalam tahap perencanaan, pengimplementasian dan evaluasinya.[]

\section{DAFTAR RUJUKAN}

A.F, Stoner James. Manajemen. Terj. Alfonsus Sirait. Jakarta: Erlangga, 1996.

Al-Thabrani. Mu'jam Al-Ausath, juz 2, Mauqi'u al-Islam: Dalam Software Maktabah Syamilah, 2005.

Antonio, Muhammad Syafi'i dan Tim Tazkia, Kepemimpinan dan Pengembangan Diri; Self Leadership dan Personal Development; Ensiklopedia Leadership dan Manajemen Muhammad SAW "The Super Leader Super Manager". Jakarta Selatan: Tazkiyah Publishing, 2011.

Fathani, Abdul Halim. Ensiklopedi Hikmah; Memetik Buah Kehidupan di Kebun Hikmah. Yogyakarta: Darul Hikmah, Tt.

Firdaus, Firdaus. "Dasar Integrasi Ilmu dalam Alquran." Al-Hikmah: Jurnal Agama dan Ilmu Pengetahuan 16.1 (2019): 23-35.

Hamalik, Oemar. Pengembangan Kurikulum dan Pembelajaran; Dasar dan Strategi Pelaksanaannya di Perguruan Tinggi. Bandung: Trigenda Karya, 1994.

Handoko, T. Hani. Manajemen. Yogyakarta: BPFE, 1986.

Hasan, S Hamid, Evaluasi Kurikulum. Bandung: SPS UPI kerjasama dengan Remaja Rosdakarya, 2008.

Hidayat, Fahri. "Pengembangan Paradigma Integrasi Ilmu: Harmonisasi Islam dan Sains dalam Pendidikan." Jurnal Pendidikan Islam 4.2 (2015): 299-318.

Kartanegara, Mulyadhi. Kata Pengantar, dalam Zaghul An-Najjar. Sains dalam Hadits; Mengungkap Fakta Ilmiah dari kemukjizatan Hadits Nabi. Jakarta: Amzah, 2011.

Kunaefi, Tresna Dermawan, et. al. Buku Panduan Pengembangan Kurikulum Berbasis Kompetensi Pendidikan Tinggi (Sebuah alternatif penyusunan kurikulum). Jakarta: Direktorat Akademik Direktorat Jenderal Pendidikan Tinggi, 2008.

Muhaimin, dkk, Pengembangan Model Kurikulum Tingkat Satuan Pendidikan (KTSP) pada Sekolah \& Madrasah. Jakarta: Raja Grafindo Persada, 2008.

Muhaimin, Nuansa Baru Pendidikan Islam; Mengurai Benang Kusut Dunia 
Pendidikan. Jakarta: Raja Grafindo Persada, 2006.

Muhaimin, Pemikiran dan Aktualisasi Pengembangan Pendidikan Islam. Jakarta: Rajawali Pers, 2011.

Muhaimin, Pengembangan Pendidikan Ulul Albab di UIN Malang dalam M.Zainuddin dkk. Memadu Sains dan Agama Menuju Universitas Islam Masa Depan. Malang: UIN Malang Press, 2004.

Mulyasa. Manajemen Berbasis Sekolah, Bandung: Remaja Rosdakarya, 2005.

Nasution S., Asas-Asas Kurikulum. Jakarta: Bumi Aksara, 2003.

Nasution, S., Kurikulum dan Pengajaran. Jakarta: Bumi Aksara, 2006.

Richard, L. Daft, Manajemen, Terj. Emil Salim, et. al. Jakarta: Erlangga, 2002.

Rusman, Manajemen Kurikulum. Jakarta: Rajawali Pers, 2009.

Syarifuddin, Yahya Ibn, Hadits Arba'in Annawawi Nomor 17.

Undang-Undang Republik Indonesia No.20 Tahun 2003, Tentang Sistem Pendidikan Nasional Bandung: Fokusmedia.

Undang-Undang Sistem Pendidikan Nasional No 20 Tahun 2003 Bab I pasal 1 ayat 19 .

Usman, Husaini, Manajemen; Teori, Praktik dan Riset Pendidikan, Jakarta: Bumi Aksara, 2010.

Zamroni. Paradigma Pendidikan Masa Depan. Yogyakarta: Bigraf Publishing, 2001. 